\title{
EDITORIAL
}

\section{Living In, and Thinking About, the World in Pandemic Times}

\author{
Kuntala Lahiri-Dutt *
}

Queen Elizabeth II famously labelled 1992 as an annus horribilis_- "terrible year" - a year that saw a fire and a scandal that ravaged British society and the royal family. When 2020 kick-started the new decade, little did we know what lay in store. In Australia, where I live, the wildfires started earlier in the year, were more widespread, and were more devastating. As the country had been in an El Nino-induced draught phase, it had not rained for several months prior to the onset of summer. Dry undergrowth provided fuel and high wind speeds allowed the fires to spread quickly, jumping across clearings, rivers, and roads, claiming several properties and much indigenous, innocent wildlife. The fires were eventually quenched, but this time by a spate of hailstorm - hail the size of golf balls crushed everything left outdoors; buildings were damaged and some beyond repair. The ongoing and unending debates on climate change-whether global warming is causing the extended xeric conditions, uncontrollable fires, and unpredictable weather-had not quite settled down when the pandemic arrived.

Interestingly, like the Black Death, COVID-19 for all practical purposes arrived in Australia by boat - a cruise boat offloading not rats but over a hundred passengers exhibiting symptoms of the illness. The pandemic does not spare anyone; like the plague, it is a great leveller. In his 1947 book, The Plague, Albert Camus wrote how epidemics do not discriminate: "The plague was no respecter of persons and under its despotic rule everyone,

\footnotetext{
* Coordinating Editor (2019-20). Crawford School of Public Policy, ANU College of Asia and the Pacific, The Australian National University, Room 3.25, JG Crawford Building, Lennox Crossing, ACTON, ACT 2601, Australia; kuntala.lahiri-dutt@anu.edu.au.

Copyright (C) Lahiri-Dutt 2020. Released under Creative Commons AttributionNonCommercial 4.0 International licence (CC BY-NC 4.0) by the author.

Published by Indian Society for Ecological Economics (INSEE), c/o Institute of Economic Growth, University Enclave, North Campus, Delhi 110007.
}

ISSN: 2581-6152 (print); 2581-6101 (web).

DOI: https://doi.org/10.37773/ees.v3i2.283 
from the Governor down to the humblest delinquent, was under the sentence and, perhaps for the first time, impartial justice reigned..." (p. 140). Unlike SARS, MERS, and Ebola, COVID-19 brought illness to everyone's doorstep. As one country after another fell prey, global resentment against China grew, and no one could pinpoint one particular factor that might have worked to keep the pandemic at bay. For example, if the wealthy northern Italian province of Lombardy had allowed its publicfunded hospital system to retreat, which led to a higher incidence of COVID-19 deaths, Britain's well-built National Health Service, one of the largest and best state-funded healthcare provision system in the world, also failed miserably in dealing with the deadly virus. Still, broadly, the experience of the USA is indicating the need for more and better statefunded public healthcare in all countries.

This is one area where India-with its multibillion-dollar healthcare and pharmaceutical industries located in metropolitan cities that attract patients from all around the world and produce the largest range of drugs-has logged an abysmal record. According to the World Health Organization, India has one of the lowest doctor-population ratios, with only 7.7 doctors per 10,000 people. The ratio is much lower than what is prevalent in other developing countries and, in fact, is closer to that of some deeply poor countries in Africa such as Sudan. Moreover, the pathetic and run-down condition of state-run hospitals puts India to shame, and more than a third of Indians aged between 15 and 49 years remain undernourished. It is no wonder then that the pandemic exposed the systemic weaknesses and inconsistencies that perpetrate the vulnerabilities of the poor, those who must move around in search of cash incomes, work in insecure and risky jobs for a basic wage, and those without a home.

The "big question" that arose, one that will be intensely debated in the future as we recover and rebuild, is about the future of the citizen-state relationship. In the last four decades, we have allowed the unprecedented retreat of the state from healthcare and education in India. The extraordinary situation brought about by the pandemic has now forced us to encounter the multifaceted ramifications of this withdrawal. We must create a more sustainable - and desirable-world for our future generations, and COVID-19 has offered us this rare opportunity. Gaps between the rich and the poor, genders, ethnicities, religions, and castes must cease to exist. Respect for nature and our relationship with it must be prioritised. Our cities must be made more liveable. The state must ensure the well-being, good health, and mental upliftment of all through education. If this sounds utopian, let me point out that not all of this is a product of my imagination. Our Sustainable Development Goals, agreements to reduce 
fossil fuel use, and many other global initiatives and processes have already agreed to the ideal of a more sustainable, equal, and just world where humans and nature no longer act as adversaries. We cannot allow "business" to run "as usual", for already the securitization of the pandemic emergency is underway in some countries. Let us now stop and reflect: do we want a big, top-heavy government to take advantage of the extreme disruptions caused by the pandemic and/or sell the inheritance of future generations-India's invaluable natural resources-to private interests so that they can accumulate surplus and generate windfall financial gains? Alternatively, could we take this opportunity to envision a novel way to be governed and use this historical moment to lead us to a collective transformative experience?

The commentaries in this EES issue further shed light on the relevance of community in a post-COVID-19 world. Research papers on arsenic pollution, the challenges of marine conservation, and flood mitigation in an environment of growing climate threats highlight, from their disciplinary perspectives, the need to find community-based solutions to our presentday pressing environmental challenges. The environment-and its conservation-holds different meanings for different communities, and our quest for a more inclusive and sustainable future should be based on a deep understanding of these differences. The special section on "new epistemologies of water" also emphasizes these understandings in the context of water resources.

The issue is being published only halfway into this horrendous year. We dread the future and worry about what other misfortunes remain hidden. Yet, we remain hopeful and ever so optimistic about humankind's ability to re-imagine and reinvent ourselves. 